\title{
Effect of Internal Control Guideline Compliance on Financial Performance of Commercial Banks in Kenya
}

\author{
Magadi Stephene Oloo ${ }^{1 *} \quad$ Waweru Gabriel ${ }^{2} \quad$ Tanui John Kipkorir ${ }^{3}$ \\ School of Business and Economics, Kabarak University, P.O Box 3270-20100 Nakuru, Kenya \\ School of Business and Economics, Meru University of Science and Technology, P.O Box 972-60200 Meru, \\ Kenya
}

\begin{abstract}
Bank failures coupled with declining profitability has been experienced in the Kenyan banking sector for a couple of years. This comes even after the Central Bank of Kenya has made concerted efforts to address the problem by introducing the risk management guidelines in 2005. In its report on the financial performance of the Kenyan banking sector for 2016/2017 financial year, banks profitability recorded a decline compared to the previous year. This situation raises the issue of whether these guidelines have had any effect on enhancing bank performance. The objective of this study was to determine the effect of board and senior management oversight guideline compliance on financial performance of commercial banks in Kenya. This study was guided by the Stakeholder theory and a descriptive research design was used. The study's target population comprised of all the 42 commercial banks licensed by the central bank to operate in Kenya. Sampling was not required since the study adopted a census of all the banks. Both secondary and primary data were used in the study. Primary data was obtained using structured questionnaires while the secondary data was collected from the audited financial reports of the commercial banks. Data analysis was done using both descriptive and inferential statistics with the help of Statistical Package for Social Sciences. The study established that board and senior management oversight guideline was a statistically significant predictor of the financial performance of the Commercial Banks in Kenya $(t=3.722 ; p=0.000)$. The findings of this study can benefit to the Central Bank of Kenya in informing the review of the guidelines, management of commercial banks in making policy decisions and other scholars in the same area of study to provide literature.
\end{abstract}

Keywords: Board and Senior Management Oversight, Commercial Banks, Financial Performance, Return on Assets

DOI: $10.7176 /$ RJFA/12-22-05

Publication date: November $30^{\text {th }} 2021$

\subsection{Introduction}

Kenya has experienced banking problems since 1986 culminating in major bank failures (37 failed as at 1998) following the crisis of 1986-1989, 1992-1994 and 1998 (Waweru \& Kalani, 2009). Before the passing of the banking Act of 1989 nine bank failures were recorded, these banks were; union bank, nationwide finance, Kenya savings and Mortgages, Jimba credit corporation, estate finance, estate building society, Citizen building society, and home savings and mortgages. Since 1999, the banking institutions in Kenya have been regulated under the Basel I Capital adequacy accord which was issued in 1988. The 1988 accord was later amended in 1996 to incorporate a capital charge for the market risk which Kenya also adopted (CBK, 2007).

Between 1993- 1995 a further 19 banks collapsed several of which had been wrapped up in the Goldenberg scandal. Some of the major failed banks during this period include; bullion bank, Trust bank, prudential bank, City finance bank and Reliance bank among others (Waweru \& Kanani, 2009). These persistent failures triggered the Central Bank of Kenya to carry out a risk management survey for the banking sector in 2004. According to the report, many banks reported that they heavily relied on the Central Bank of Kenya's prudential returns to monitor risks, due to the absence of internal risk management information systems (CBK, 2010). In response to the bank risk management survey conducted in 2004, the central bank introduced the risk management guidelines (RMGs) in 2005 to assist institutions under its purview in formulating and implementing internal risk management policies and procedures with a view to better monitor, measure and report risks, and this was also in addition to enforcement of the Basel II principles which were issued in 2004 by the Basel Committee on Banking Supervision (CBK, 2013). Among the guidelines which were introduced by the Central bank of Kenya was board and senior Management oversight. All the commercial banks under the purview of the supervision of the central banks were required to comply with these guidelines.

The guideline on board and senior management oversight stipulates that boards have the ultimate responsibility for the level of risk taken by their institutions. They should approve the overall business strategies and significant policies of their organizations. Senior management, on the other hand, is responsible for implementing strategies approved by the board in a manner that limits the risks associated with each strategy. They should be fully involved in the activities of their institutions and should possess sufficient knowledge of all business lines to ensure that appropriate policies, controls, and risk monitoring systems are in place. This guideline 
will ensure effective implementation and control of risk management strategies (CBK, 2013).

According to the Kenyan financial stability report, 2016 the banking sub-sector recorded elevated credit risk which reflected in the deterioration of their asset quality following increased non-performing loans (NPLs) and provisions (CBK,2017). The gross NPLs increased by 106 percent in the year to December 2016 compared to 30.14 percent in the year December 2015 (CBK, 2017). The sector also recorded a 10.9 percent increase in profits in the year to December 2016 but 11.7 percent decline in profitability in the year to March 2017 . The gross ratios of nonperforming loans (NPL, s) to gross loans increased from 8.3 percent in March 2016 to 9.5 percent in March, additionally between 2013 to March 2017 a total of seven banks have been or are in the process of being acquired or merged with others (CBK, 2017). According to the central bank's annual report for 2016/2017 on financial position and performance of the Kenyan banking sector profits before tax decreased by $14.6 \%$ from Kshs. 81.2 billion in the year to 30 June 2016 to Kshs. 69.3 billion in the year to 30 June 2017. These statistics point towards a situation where by financial institutions in the Kenyan are struggling to remain profitable in the sector.

\subsection{Statement of the Problem}

Commercial banks in Kenya have continued to face a myriad of challenges in their operations and also vulnerability to both domestic and external shocks. This was evidenced by placement of one bank into liquidation in the second half of 2015 (Dubai Bank) and two other banks into receiverships in the first quarter of 2016 (Imperial Bank and Chase Bank) (Gathaiya, 2015). This came against the backdrop of the implementation of the risk management guidelines by the Central Bank of Kenya in early 2005. Additionally, between 2013 and 2017, a total of seven banks were in the process of being acquired or merged with other banks (CBK, 2017). These banks included; Habib Bank Ltd, Fidelity Commercial Bank, Oriental Commercial bank, Equatorial Commercial Bank, Giro Commercial Bank, K-rep Bank, and Fina Bank. Another two banks, Commercial bank of Africa and NIC Banks are also merged by the end of the year 2019. One of the key drivers for Mergers and Acquisitions is an attempt to reduce risk of bank failure and curtail costs (both financial and social).

According to the Kenyan financial stability report of 2016 the banking sub-sector recorded elevated credit risk which reflected in the deterioration of their asset quality following increased non-performing loans (NPLs) and provisions (CBK, 2017). The gross NPLs increased by 106 percent in the year to December 2016 compared to 30.14 percent in the year December 2015 (CBK, 2017). The sector also recorded a 10.9 percent increase in profits in the year to December 2016 but 11.7 percent decline in profitability in the year to March 2017 . The gross ratios of nonperforming loans (NPL, s) to gross loans increased from 8.3 percent in March 2016 to 9.5 percent in March, additionally between 2013 to March 2017 a total of seven banks have been or are in the process of being acquired or merged with others. (CBK, 2017). According to the central bank's annual report for 2016/2017 on financial position and performance of the Kenyan banking sector profits before tax decreased by $14.6 \%$ from Kshs. 81.2 billion in the year to 30 June 2016 to Kshs. 69.3 billion in the year to 30 June 2017. These statistics point towards a situation where financial institutions in the Kenyan are struggling to remain profitable in the sector. Empirical studies that have been carried out in Kenya have not specifically addressed the effectiveness of the Central Bank's risk management guidelines. This study, therefore, seeks to fill this gap by examining all the five the components of the risk management guidelines which are commonly used and applicable in commercial banks in Kenya.

\subsection{Objective of the Study}

To establish the effect of the Internal Controls System Guideline compliance on Financial Performance of Commercial Banks in Kenya

\subsection{Hypothesis of the Study}

HO: Internal Controls System Guideline Compliance does not affect Financial Performance of Commercial Banks in Kenya

\subsection{Literature Review}

This section reviewed the theoretical literature and the Empirical Literature. Theoretical literature involved the review of theories that underpin the study while empirical literature reviewed past studies that were relevant to the objective under this study.

\subsection{Theoretical Literature}

This study was guided by systems theory. Systems theory can be traced back to the works of Bertalanffy (1968). Systems theory is the transdisciplinary study of the abstract organization of phenomena, independent of their substance or type. It investigates both the principles common to all complex entities and the models which can be used to describe them (Bertalanffy, 1968). A system is a set of interrelated and independent components that interact in a way to achieve a set goal. These components or subsystems are inter-dependent and failure of one 
component leads to the failure of the whole system. An organization is a complex system which is divided into sub-systems and hence requires a system of control over the sub-systems for its effectiveness and survival (Ayagre, Gyamerah \& Nartey, 2014).

Banks have an internal control system which should not only ensure their proper functioning but also ensure that their assets are safeguarded. According to the Central Bank of Kenya (2013), an institution's internal control structure is critical to the safe and sound functioning of the organization in general and to its risk management in particular. A well-functioning internal control system should ensure that all material risks to which an organization is exposed to are prevented or mitigated (CBK, 2013). Harvey and Brown (1998) identified a controlled environment, accounting system, and control procedures as the major components of internal control. According to Grieves (2000) an internal control system available to a firm consists of; Management oversight and control culture, risk recognition and assessment, control of activities and segregation of duties, information and communication, and monitoring activities.

Jin, Kanagaetnam, Lobo \& Mathiew, (2013) found that banks without proper internal controls could grow temporarily but they have a higher likelihood of failing in the near future. In tracing the path to bank failure, the first stop point is credit risk which is experienced through borrowers default before liquidity and insolvency sets in. The trajectory of bank failure follows that credit risk leads to liquidity risk then to insolvency, bankruptcy and then failure (Sekyi \& Gene, 2016). According to Mawanda (2008), designing and implementation of proper internal controls will always lead to improved performance. In his study on the effects of internal controls on the financial performance of commercial banks in Kenya Rennox (2017) noted that effective internal controls reduce the risk of fraud and bad debts. Therefore systems theory was used to guide the study in establishing the effect of the internal controls system and capital and liquidity limits on the financial performance of Commercial Banks in Kenya.

\subsection{Empirical Review}

An Internal control is defined as the process effected by an entity's board of directors, management and other personnel, designed to provide reasonable assurance regarding the achievement of the objectives in the following categories: effectiveness and efficiency of operations, reliability of financial reporting, compliance with applicable laws and regulations and safeguarding the Assets (Ayagre, Appiah-Gramerah \& Nartey, 2014). Effectiveness of internal controls on the performance of banks has attracted various studies both locally and globally (Ayagre et. al., 2014, Kumuthinidevi, 2014, Rennox, 2017). Internal controls are important to all business organizations and more so the banking sector whose business environment is prone to risks which must be mitigated for performance and profitability (Rennox, 2017).

Kumuthinidevi (2016) carried out a study on the effectiveness of the internal control system in the private banks of Trincomalee, Sri Lanka. The study used both secondary and primary data. Questionnaires were distributed among permanent staff of ten banks. Univariate and well as bivariate analysis methods were used to analyse the data. Study finding indicated that all the study variables which included control environment, risk assessment, accounting information and communication, control activities and self-assessment were moderately supportive in the effectiveness of internal control systems. Ayagre et al., (2014) examined the effectiveness of internal control systems of banks in Ghana. Data for the study was gathered using questionnaires administered to managers of all banks in Ghana. Statistical package for social sciences (SPSS) was used to analyse the data. Study findings indicated that strong controls exist in the control environment and monitoring activities components of the internal control systems of banks in Ghana.

Sekyi \& Gene (2014) examined the effect of internal control on credit risk among listed Spanish banks. They used a quantitative research approach to test the hypothesis on the relationship between internal control and credit risk among listed banks in Spain. Data from bank scope and company websites from 2003 -2014 were used. The results of the study showed that internal controls explain credit risk very much. The R-squared value of the study indicated that $72 \%$ of the variations in credit risk were attributable to internal controls. Rennox (2017) also studied the effect of internal controls on the financial performance of commercial banks in Kenya. The study used 43 commercial banks and primary data was collected using a structured questionnaire. Descriptive statistics were obtained from the data and inferential findings were the relationship between internal control and financial obtained presented using correlations and regression tables. The study findings revealed that commercial banks that effectively implemented elements of internal control had relatively better financial performance. Regression results showed that there was a significant positive association between internal controls and financial performance of commercial banks in Kenya.

\subsection{Conceptual Framework}

The study was guided by the conceptual framework illustrated in Figure 1. The independent variable was Internal Control system Compliance while the dependent variable was financial performance measured by Return on Assets (ROA) 


\begin{tabular}{|cl}
\hline $\begin{array}{l}\text { Internal } \\
\text { Guideline }\end{array}$ & Control Systems \\
$\bullet$ & Appropriateness \\
$\bullet$ & Organization structures \\
$\bullet$ & Independence \\
$\bullet$ & Reliability, accuracy \\
& and timeliness \\
$\bullet$ & Review \\
& Compliance \\
& \\
\end{tabular}

Financial Performance

- $\quad$ ROA

Figure 1: Conceptual Framework

\subsection{Methodology}

The study adopted the positivist philosophy. This philosophy involves exploring social reality based on philosophical ideas of the French philosopher August Comte (Antwi \& Hazma, 2015). The philosophy was suited for this study due to a number of reasons. First, positivists approach relies heavily on numerical data (Gall, Gall $\&$ Borg, 2003). For the quantitative approach, a positivist philosophy applies. The use of quantification to represent and analyze the features of social reality is consistent with positivistic philosophy (Rehman \& Alharthi, 2016). This study used quantitative data that was collected from the secondary data and the questionnaire.

The study used descriptive research design. The goal of descriptive research design is to describe a phenomenon and its characteristics without manipulation (Gall \& Borg, 2007). A descriptive design was preferred for this study because it allows for the collection of large quantifiable information to be used for the statistical analysis of the population sample. The population of the study comprised of all the 42 commercial banks licensed to operate in Kenya. The study adopted a census method to select all the 42 commercial banks. This study used both primary and secondary data. Secondary data was collected using a data collection form that was designed to capture the required information from the financial statements of the commercial banks published in banking survey of Kenya report. Primary data, on the other hand, was collected using structured questionnaires. Cronbach alpha was employed to test for the reliability of the research Instrument.

\subsection{Data processing and Analysis}

The effect of Internal Control Systems guideline compliance on financial performance of commercial banks in Kenya was evaluated by applying simple regression analysis. Financial performance variable (ROA) and board and Internal Control Systems Guideline (ICGC) were regressed using SPSS software. The following regression equation was run to estimate the effect of Internal Control Systems Guideline compliance on Financial Performance

ROA $=\beta_{0}+\beta_{1} I C G C+\varepsilon$

Where;

ROA $=$ Return on Assets as a measure of Financial performance of Commercial Banks

$\beta_{0}=$ Constant

$\beta 1=$ Coefficient of Internal Control Systems Guideline Compliance

ICGC $=$ Internal Control Systems Guideline Compliance

$\varepsilon=$ Margin of error

\subsection{Results, Interpretations, and Discussions}

In this section, the descriptive and inferential results are presented. The results are accompanied by pertinent interpretation and discussions and are aligned to the study objective and research hypothesis.

\subsection{Reliability Results}

According to the study findings, both variables were found to be reliable since they returned alpha values greater than the minimum acceptable threshold of 0.7 as shown in Table 1.

\section{Table 1: Reliability Test Results}

\begin{tabular}{lrr}
\hline Variable & Test Items & Cronbach's Alpha Value \\
\hline Internal control systems guideline & 9 & 0.835 \\
\hline
\end{tabular}




\subsection{Financial Performance of Commercial Banks in Kenya}

The paper further collected secondary data on the return on assets from 42 licensed commercial banks in Kenya for the period of 10 years starting from 2008 to 2017. The collected data was then analyzed using descriptive statistics. The results to this effect are presented in Figure 2. According to these results, the return on assets (ROA) was fluctuation with the highest average return on assets being 2.796 for the year 2013 and lowest being 1.067 for the year 2017. The study further noted that from the year 2013 when the highest levels of return on assets were achieved, there has been a steady decline in the return of assets for the subsequent years to 2017 . This could have been caused by steady decline in the Kenyan Economy and also the introduction of interest rates caps (Central Bank of Kenya, 2016, 2017).

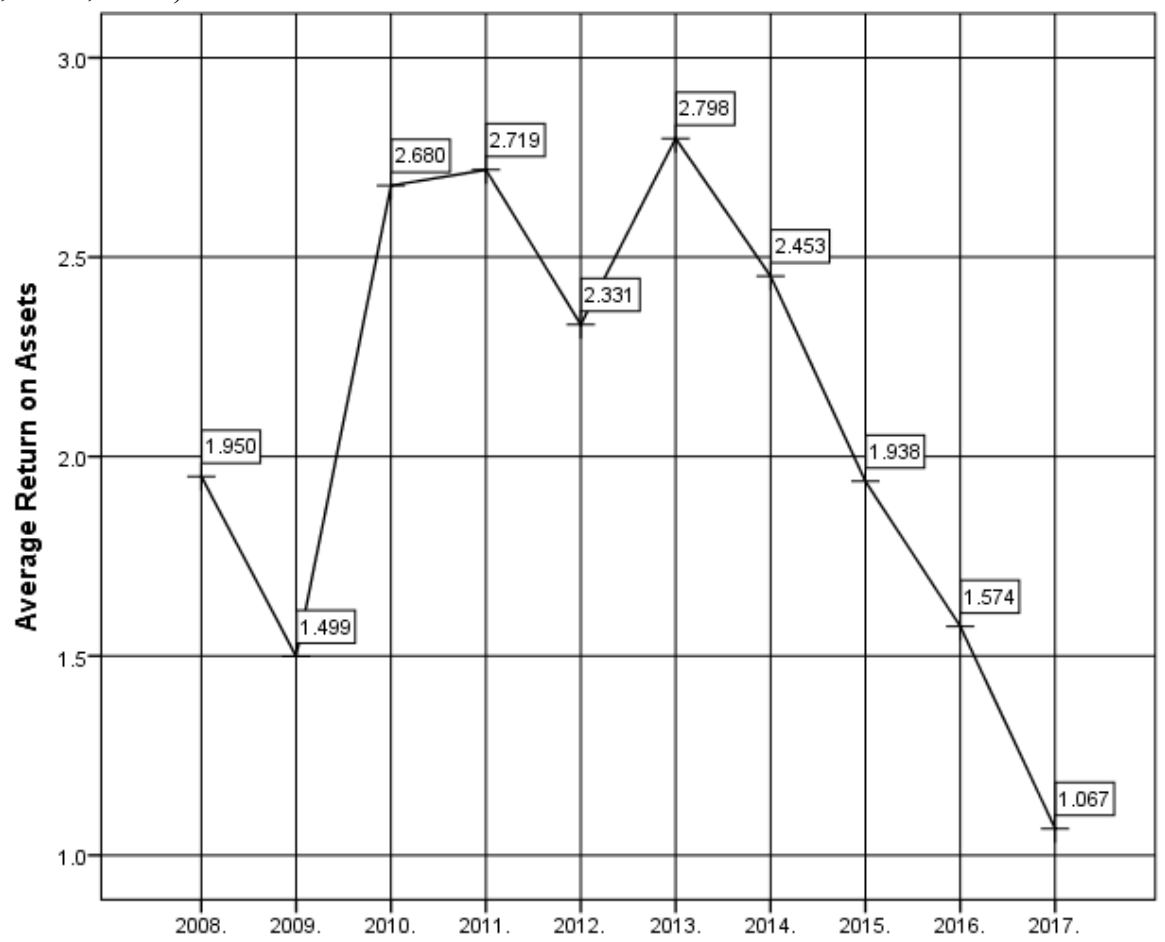

Figure 2: Average Return on Assets for the Period 2008 to 2017

\subsection{Inferential Statistics}

Under inferential statistics, simple linear regression analysis was used to establish the effect of Internal Control Systems guidelines on financial performance of commercial banks licensed to operate in Kenya. The pertinent results are presented in Table 4, Table 5, and Table 6 respectively. The results shown in Table 4 indicate that the relationship between board and senior management oversight guidelines and financial performance was positive and moderately strong $(\mathrm{r}=0.320)$. According to the results of coefficient of determination $\left(\mathrm{r}^{2}=0.102\right), 10.2 \%$ of the variation in financial performance could be explained by the aforesaid guidelines. The results underline the considerable extent to which the guidelines with regard to Internal Control Systems Guidelines were important in influencing financial performance of commercial banks in Kenya.

Table 4: Model Summary

\begin{tabular}{lrrrr}
\hline Model & $\mathbf{r}$ & r Square & Adjusted r Square & Std. Error of the Estimate \\
\hline 1 & $.320^{\mathrm{a}}$ & .102 & .080 & 2.82946 \\
\hline
\end{tabular}

\section{a. Predictors: (Constant), ICGC}

The results of F-statistics shown in Table $5\left(\mathrm{~F}_{1,41}=4.568 ; \mathrm{p}=0.039\right)$ were found to be statistically significant at $p$-value $=0.05$. This implied that the sample data fitted the adopted linear regression model $\left(Y=\beta_{0}+\beta_{1} X_{1}+\varepsilon\right)$. Consequently, it was practical to establish the effect of Internal Control Systems guidelines on financial performance as shown in Table 5 .

Table 5: ANOVA

\begin{tabular}{lrrrrrr}
\hline Model & Sum of Squares & df & Mean Square & F & Sig. \\
\hline Regression & 36.571 & 1 & 36.571 & 4.568 & $.039^{\mathrm{b}}$ \\
Residual & 320.234 & 40 & 8.006 & & & \\
Total & $\mathbf{3 5 6 . 8 0 5}$ & $\mathbf{4 1}$ & & & & \\
\hline
\end{tabular}

a. Dependent Variable: Financial Performance (Return On Assets)

b. Predictors: (Constant), Internal Control Guidelines Compliance 
As shown in Table $6\left(\mathrm{Y}=-11.568+3.477 \mathrm{X}_{1}\right)$, a unit change in Internal Control Systems Guideline Compliance is subject to 3.477 change in Financial Performance when other factors were held constant. According to the results of $\mathrm{t}$-statistics $(\mathrm{t}=2.137 ; \mathrm{p}=0.039)$ it was revealed that the effect of the aforementioned guideline on financial performance was statistically significant at $\mathrm{p}$-value $=0.05$. Therefore, the research hypothesis (Internal Control Systems Guideline Compliance does not affect the financial performance of financial Institutions in Kenya) was rejected.

Table 6: Regression Coefficients

\begin{tabular}{|c|c|c|c|c|c|}
\hline \multirow[b]{2}{*}{ Model } & \multicolumn{2}{|c|}{ Unstandardized Coefficients } & Standardized Coefficients & \multirow[b]{2}{*}{$\mathbf{t}$} & \multirow[b]{2}{*}{ Sig. } \\
\hline & B & Std. Error & Beta & & \\
\hline 1 (Constant) & -11.568 & 6.275 & & -1.844 & .073 \\
\hline ICGC & 3.477 & 1.627 & .320 & 2.137 & .039 \\
\hline
\end{tabular}

a. Dependent Variable: Financial Performance (ROA)

\subsection{Summary, Conclusions and Recommendations}

The study summarized the findings in line with the variable and objective of the study. This was followed by drawing of the relevant conclusions. Finally recommendations for appropriate actions were suggested

\subsection{Summary}

The study sought to determine the effect of internal controls guidelines compliance on financial performance of commercial banks in Kenya. The study established that there was a statistically significant association between financial performance of commercial banks in Kenya and various components of internal controls. In respect to this, systems of internal control being appropriate to the type and level of risks posed by the nature of the institution's activities, institutions audit committee or board of directors reviewing the effectiveness of controls, and organization structure establishing clear lines of authority and responsibility for monitoring adherence to procedures were found to have a statistically significant association with financial performance of commercial banks in Kenya at 5\% significance level. Reporting lines providing sufficient independence of the control areas from business lines throughout the institution, exceptions noted on the reports being promptly investigated, information system being adequately reviewed, various bank reports being always reliable and control review practices providing for independence in the bank operations were also found to be statistically and significantly associated with financial performance of commercial banks in Kenya at 5\% significance level. Focusing on whether the internal controls variable was a statistically significant predictor of financial performance, the study found out that $\mathrm{P}(\mathrm{t} 0.25,71>6.648)<0.05$. Therefore, a decision was made to reject the third null hypothesis stating that; $\mathrm{Ho}_{3}$ : Internal controls do not affect financial performance of commercial banks in Kenya. The study thus established that internal controls had a statistically significant effect on financial performance of the commercial banks in Kenya. In respect to the internal controls, a unit increase in the internal controls was associated with 0.163 increase in the financial performance of commercial banks with the other variables kept constant. This was due to unstandardized beta coefficient of 0.163 on internal controls guidelines.

\subsection{Conclusions}

The study also concluded that there was statistically significant effect of internal controls guideline on financial performance of commercial banks in Kenya. In respect to this, the study concluded that the major aspects of internal controls guideline used by the commercial banks in Kenya included having systems of internal control which were appropriate to the type of risks posed by the nature of the institution's activities, having institutions audit committee or board of directors reviewing the effectiveness of controls, organization structure establishing clear lines of authority for monitoring adherence to procedures and having information system adequately reviewed. It was also concluded that an improvement in the internal controls guideline leads to the improvement in financial performance of commercial banks in Kenya.

\subsection{Recommendations}

In respect to internal control guidelines compliance, the study recommends that commercial banks in Kenya to improve on the systems of internal control in order to be appropriate to the level of risks posed by the nature of the institution's activities and also ensure that exceptions noted on the internal control reports are promptly investigated while ensuring the internal control practices are as independent as possible. These aspects were rarely done and thus the reason for this recommendation.

\section{REFERENCES}

Antwi, S. K., \& Hamza, K. (2015). Qualitative and quantitative research paradigms in business research: A philosophical reflection. Journal of Business and Management, 7(3), 217-225.

Ayagre, P., Appiah-Gyamerah, I., \& Nartey, J. (2014). The effectiveness of internal control systems of banks: The 
case of Ghanaian banks. International Journal of Accounting and Financial Reporting, 4(2), 377.

Central Bank of Kenya (CBK). (2013). Risk management guidelines. Nairobi Kenya: Central Bank of Kenya.

Central Bank of Kenya. (2017). Kenya's financial sector stability report 2016. Nairobi: Central Bank of Kenya.

Gall, M. D., Gall, J. P., \& Borg, W. R. (2003). Educational research: An introduction (7th ed.). Boston, MA: Pearson's Publishers.

Gathaiya, R. N. (2017). Analysis of issues affecting collapsed banks in Kenya from the year 2015 to 2016. International Journal of Management and Business Studies, 7(3), 9-15.

Grieves, J. (2000). Introduction: The Origin of Organization Development, Journal of Management Development, 19(5), 345

Harvey, D., \& Brown, D. (1998). An Experimental Approach to Organization Development, $3^{\text {rd }}$ Ed. Prentice Hall, 68

Jin, J.Y., Kanagaetnam, K., Lobo, G. J., \& Mathiew, R. (2013). Impact of FDICIA Internal Controls on Banks risktaking, A Journal of Banking and Finance, 37(2), 614-624

Kumuthinidevi, S. (2016). A study on effectiveness of internal control system in the private banks of Trincomalee. International Journal of Scientific and Research Publications, 6(6), 31-53.

Mawanda, S. (2008). Effects of internal control system on financial performance in Uganda's institution of higher learning, Dissertation for award of MBA in Uganda Martyrs University

Rehman, A.A. \& Alharthi, K. (2016). An Introduction to Research Paradigm, International Journal of Educational Investigations, 3(8), 51-59

Rennox, A. G. (2017). The effect of internal controls on the financial performance of commercial banks in Kenya. Journal of Economics and Finance, 8(3), 92-105.

Akwaa-Sekyi, E. K., \& Moreno Gené, J. (2016). Effect of internal controls on credit risk among listed Spanish banks. Intangible Capital, 12(1), 357-389.

Von Bertalanffy, L. (1968). General systems theory: Foundations, development. New York, NY: George Braziller.

Waweru, C., \& Ngugi, K. (2014). Influence of Financial Management Practices on the Performance of Micro and Small Enterprises in Kenya Charles Waweru. European Journal of Business Management, 1(11), 141-161.

\section{Author Profiles}

Magadi S. Oloo is a Lecturer in the School of Business and Economics in the Department of Accounting and Finance at Kabarak University. He is currently pursuing Doctor of Philosophy in Business Administration (Finance Option) at Kabarak University. He holds an MBA, Finance Option (JKUAT) and a B.com (Finance option from Kabarak University, $\mathrm{CPA}(\mathrm{K})$ and $\mathrm{CSIA}(\mathrm{K})$ both Professional courses Examined by Kenya Accountants and Secretaries National Examination Board (KASNEB). He previously worked as a lecturer at MIS College of Accountancy and Information Technology, Achievers School of Professional Studies and Flamingo College of Accountancy

Dr. Gabriel Waweru is a Lecturer in the School of Business and Economics, in the Department of Accounting and Finance at Meru University of Science and Technology (MUST). He holds a PhD in Business Administration (Accounting and Finance) from University of Cape Town, South Africa, A Master's Degree in Business Administration (Finance), and a Bachelor of Science in Applied Accounting, CPA (K), and CPS (K). Dr Gabriel has vast experience in the academia having taught for the last 17 years both at the University and at tertiary colleges. He has published widely in accounting, taxation and finance. Formally, Dr. Gabriel taught CPA courses at Achievers School of Professionals, Nakuru.

Dr. John Kipkorir Tanui is a senior Lecturer in the School of Business and Economics, in the Department Commerce of Kabarak University. He holds a PhD in Agricultural Economics from Nanjing University China Master's Degree in Agricultural Economics, Moi University and Bachelor's degree in Agriculture University from University of Nairobi. He has published widely with over seventy publications, a number of book chapters and three books currently working on the fourth one. He has developed a variety of value added products, on tea and herbals for local and international markets, Aloe Vera (Turkanesnsis), value added products, several composite Organic fertilizers, and a patent in affluent treatment. Dr Tanui has made a number of research linkages with international Universities. Two of his research projects papers adopted by United Nations, Food and Agricultural Organization, United States Department of Agriculture and Chinese academy of science as a reference material. $\mathrm{He}$ is excellent in use of data analysis software such as Eviews, SPSS, STATA, and R for statistical analysis of quantitative data. He is a member of several international academic organizations, and participates on current research in his field especially in Econometric society and research methodology groups. He taught in Moi University and University of Eldoret. Agribusiness, Econometrics, research methods, among others 